\title{
SOSIALISASI PRODUK INDUSTRI RUMAH TANGGA (PIRT) BAGI UMKM PISANG SALEE
}

\author{
Anna Malia ${ }^{1}$, Sri Wahyuni ${ }^{2}$, Ernawita ${ }^{3}$, Dewi Maritalia ${ }^{4}$ \\ 14 Dosen Program Diploma III Kebidanan Universitas Almuslim \\ ${ }^{2}$ Dosen Program Studi Ekonomi Pembangunan Fakultas Ekonomi Universitas Almuslim \\ ${ }^{3}$ Dosen Program Studi Agroteknologi Fakultas Pertanian Universitas Almuslim \\ Email: amalia.anwar33@gmail.com,wahyuni1313@gmail.com, \\ ernawita.ernawita@gmail.com,dewi.maritalia@gmail.com
}

\begin{abstract}
ABSTRAK
Kota Panton Labu Kabupaten Aceh Utara merupakan salah satu daerah penghasil pisang salee yang cukup terkenal dan sering dikunjungi masyarakat untuk membeli pisang salee. Namun, produk pisang salee yang dihasilkan oleh UMKM di Panton Labu masih banyak yang belum memiliki surat izin PIRT. PIRT merupakan bentuk jaminan dari pemerintah mengenai makanan yang diproduksi aman untuk dikonsumsi oleh konsumen. Kegiatan PKM ini bertujuan untuk meningkatkan pengetahuan dan pemahaman pelaku usaha pisang salee/UMKM tentang pentingnya PIRT bagi suatu produk makanan. Metode yang digunakan dalam pelaksanaan kegiatan PKM ini adalah dengan melakukan sosialisasi tentang PIRT dan prosedur mendapatkan PIRT pada beberapa UMKM pisang salee yang ada di Kota Panton Labu Kabupaten Aceh Utara. Alat dan bahan yang digunakan dalam sosialisasi tersebut adalah beberapa contoh produk makanan dari UMKM yang sudah memiliki PIRT dan sudah dikemas dengan baik. Setelah mendapatkan sosialisasi tentang PIRT disertai beberapa contoh produk makanan, terlihat bahwa pelaku usaha pisang salee/UMKM tertarik dan antusias untuk mendapatkan PIRT bagi produknya. Oleh karena itu, kegiatan PKM ini perlu ditindaklanjuti dalam bentuk pendampingan pada UMKM pisang salee di Kota Panton Labu dalam mendapatan PIRT dan kemasan produk yang lebih baik.
\end{abstract}

Kata Kunci: pangan, pirt, pisang salee, sosialisasi, umkm

\begin{abstract}
Panton Labu City, North Aceh Regency is one of the famous pisang salee (smoked banana)-producing areas and is often visited by the public to buy pisang salee. However, there are still many pisang salee products produced by MSMEs in Panton Labu that do not have a Home Industry Product (PIRT) permit. PIRT is an assurance from the government regarding the food produced is safe for consumption by consumers. This community service aims to increase the knowledge and understanding of pisang salee business actors/MSMEs about the importance of PIRT in a food product. The method used was socialization to several pisang salee MSMEs in the city of Panton Labu, North Aceh Regency regarding PIRT and the procedure for getting PIRT. The tools and materials used in the socialization were some sample products from MSMEs that already have PIRT and are packaged properly. After receiving socialization about PIRT which was accompanied by several examples of food products, pisang salee business actors/MSMEs were interested and enthusiastic to get PIRT for their products. This community service needs to be followed up in the form of assistance
\end{abstract}


to pisang salee MSMEs in Panton Labu City in getting PIRT and better product packaging.

\section{Key Words : banana salee, food, msme, socialization}

\section{PENDAHULUAN}

Bisnis kuliner/makanan merupakan salah satu bisnis yang berkembang pesat di masyarakat, terlebih di area seputar tempat wisata yang dijadikan sebagai oleh-oleh khas daerah wisata. Makanan merupakan olahan pangan dari Sumber Daya Alam yang diolah dan diproduksi untuk memenuhi kebutuhan konsumen. Hal tersebut menjadikan pelaku UMKM meningkat dalam melakukan produksi produk pangan atau makanan yang dapat menghasilkan pundi rupiah untuk rumah tangga (BPOM, 2018).

Menurut Undang-undang No. 36 Tahun 2009 tentang Kesehatan menjelaskan bahwa pemerintah berkewajiban untuk menjaga agar makanan memenuhi standar mutu gizi yang ditetapkan dengan peraturan perundang-undangan, yang berbunyi bahwa pemerintah daerah, dan/atau masyarakat bersama-sama menjamin tersedianya bahan makanan yang mempunyai nilai gizi tinggi secara merata dan terjangkau. Hal ini menunjukkan bahwa menjadi tugas dan perhatian penting baik bagi pemerintah dan produsen makanan untuk menjaga dan menjamin kualitas makanan yang diproduksi, dari segi kebersihan, keamanan, nilai gizi dan lainnya. Salah satu bentuk jaminan tersebut adalah adanya surat izin PIRT oleh produsen di bidang bisnis kuliner/makanan.

Pisang salee merupakan makanan khas Aceh Utara dan dijadikan oleh-oleh untuk wisatawan yang singgah di Aceh Utara. Kota Panton Labu merupakan daerah di Aceh Utara yang terkenal dengan produksi pisang salee-nya. Produk pisang salee dari Panton Labu dijual di kabupaten sekitar, seperti Lhokseumawe, Bireuen dan Langsa. Bahkan menjadi oleh-oleh khas Aceh bagi masyarakat provinsi lain seperti Sumatera Utara. Namun, pemasaran produk pisang salee yang semakin meluas tersebut tidak diiringi dengan peningkatan kualitas produk. Hal ini terlihat belum adanya surat izin PIRT untuk produk pisang salee tersebut. Bahkan, pelaku usaha pisang salee belum mengetahui apa itu surat izin PIRT dan pentingnya label PIRT bagi produk makanan. Pelaku usaha pisang salee membuat pisang salee berdasarkan ilmu yang diajarkan orang 
tua atau keluarga secara turun temurun. Proses pembuatannya juga masih tradisional dan belum ada sentuhan alat-alat modern/mesin, seperti terlihat pada gambar berikut:

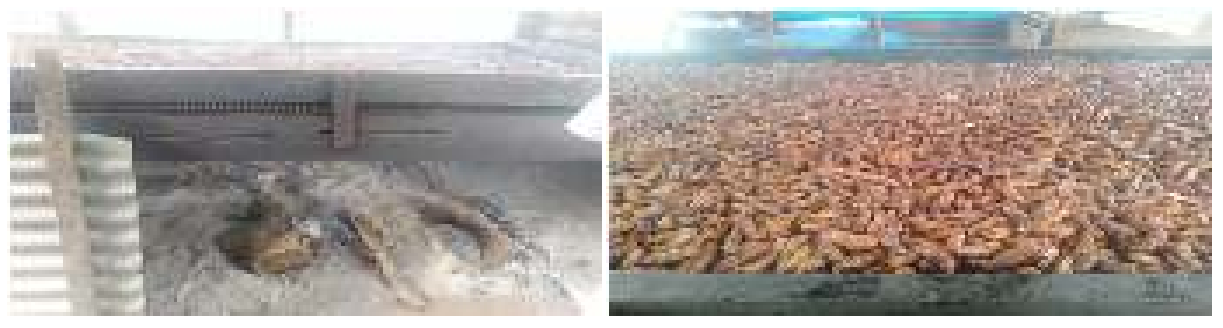

Gambar 1. Proses Pembuatan Pisang Salee

Pangan Industri Rumah Tangga (PIRT) merupakan izin produksi pangan yang diberikan kepada pelaku usaha skala industri rumah tangga. Surat izin diberikan secara resmi kepada pelaku industri setelah sebelumnya ditetapkan oleh BPOM (Badan Pengawasan Obat dan Makanan). Surat izin PIRT ini diberikan sebagai salah satu bentuk jaminan kesehatan, keamanan dan kebersihan yang ditetapkan oleh pemerintah terhadap produksi pangan kepada konsumen (Kurniawan, 2018).

Selain itu, pelaku usaha kuliner pisang salee juga tidak memperhatikan kemasan produk pisang salee yang akan dipasarkan (Sucipta, 2017). Hal ini dikarenakan pelaku usaha tersebut belum memahami pentingnya kemasan dalam meningkatkan mutu dan nilai jual produk yang dapat menarik minat pembeli. Produk pisang salee yang dihasilkan selama ini dijual dengan menempatkannya dalam wadah plastik putih setelah ditimbang dalam beberapa ukuran, seperti $250 \mathrm{gr}, 500 \mathrm{gr}$ dan $1 \mathrm{~kg}$, yang terlihat pada gambar berikut:
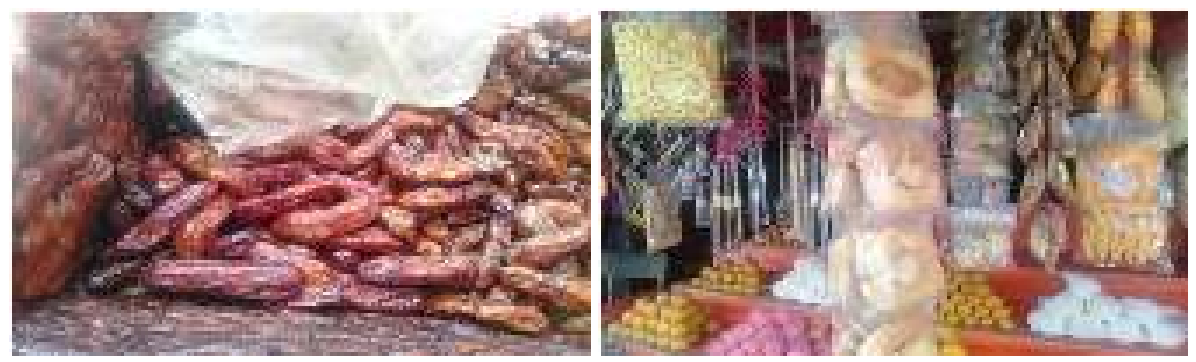

Gambar 2. Kemasan Pisang Salee yang Belum PIRT

Pengembangan Usaha Mikro Kecil Menengah (UMKM) di daerah khususnya daerah wisata perlu didukung guna meningkatkan perekonomian daerah dan mengurangi tingkat pengangguran. UMKM mempunyai peran strategis untuk membangun ekonomi dan menjadi penggerak orang-orang di pedesaan atau perkotaan (Hafni, 2017). 
Oleh karena itu, Pengabdian kepada Masyarakat ini bertujuan untuk meningkatkan pengetahuan dan pemahaman pelaku usaha kuliner pisang salee/UMKM akan pentingnya PIRT bagi produk makanan. Adanya label PIRT pada produk makanan akan meningkatkan kepercayaan masyarakat untuk mengkonsumsi produk tersebut, karena sudah diproses sesuai standar Good Manufacturing Practice (GMP) dan menjadikan produk dapat dijual ke pasar yang lebih besar.

\section{METODE PELAKSANAAN}

Pelaksanaan kegiatan Pengabdian kepada Masyarakat ini dilakukan oleh tim dosen Universitas Almuslim dari berbagai bidang ilmu, yang melalui beberapa tahapan, yaitu:

1. Survey lokasi, yaitu lokasi PKM ini merupakan rekomendas tim Lembaga Penelitian dan Pengabdian kepada Masyarakat (LPPM) Universitas Almuslim. Hal ini dikarenakan banyaknya UMKM pisang salee di Kota Panton Labu Kabupaten Aceh Utara, namun tidak memiliki PIRT yang menjadi standar produk bagi pelaku usaha kuliner. Survey lokasi dilakukan pada April tahun 2021 bersama tim dari LPPM.

2. Mengidentifikasi data pelaku usaha pisang salee/UMKM pisang salee dan produk yang dihasilkan, yaitu setelah melakukan survey, dilanjutkan dengan mendata UMKM Pisang Salee di Kota Panton Labu Kabupaten Aceh Utara. Hasil indentifikasi diperoleh lebih kurang 10 (sepuluh) UMKM Pisang Salee yang diproduksi dan dikelola secara tradisional sebagai usaha turun temurun keluarga dan belum memiliki PIRT.

3. Melakukan sosialisasi PIRT dan kemasan kepada pelaku usaha pisang salee/UMKM pisang salee, yaitu sosialisasi PIRT dilakukan secara bergantian dari satu UMKM ke UMKM lain menginggat masih dalam suasana pandemi Covid-19, untuk mengurangi berkumpul/berkerumunnya masyarakat dalam mencegah penularan virus Covid-19. Sosialisasi dilakukan dalam 1 (satu) hari dengan durasi sekitar 90 sampai 120 menit untuk setiap UMKM.

4. Melakukan evaluasi kegiatan dan pembuatan laporan pelaksanaan, yang dilaksanakan setelah sosialisasi PIRT pada UMKM pisang salee. Hasil evaluasi menunjukkan bahwa pelaku usaha pisang salee sangat antusias dan tertarik mengurus PIRT untuk produk pisang salee-nya. Bahkan ada yang meminta dilakukan pendampingan pengurusan PIRT karena belum mengetahui prosedurnya. 


\section{HASIL DAN PEMBAHASAN}

Sosialisasi yang dilakukan terhadap UMKM Pisang Salee di Kota Panton Labu Kabupaten Aceh Utara menghasilkan beberapa dampak positif sebagai berikut:

1. Bertambahnya pengetahuan dan pemahaman pelaku pengusaha pisang salee dari beberapa UMKM tentang pentingnya PIRT bagi produk UMKM berupa makanan. Ada serangkaian proses yang harus dilalui oleh UMKM yang memproduksi makanan untuk memperoleh PIRT. Rangkaian proses tersebut merupakan Good Manufacturing Practice yang menerapkan konsep manajemen berbentuk prosedur dan cara kerja dalam menghasilkan produk, sehingga produk tersebut terstandar dengan tingkat perbedaan yang sangat rendah untuk setiap produk yang dihasilkan.

2. Meningkatnya pengetahuan dan pemahaman pelaku pengusaha pisang salee dari beberapa UMKM tentang pentingnya kemasan produk yang baik untuk peningkatan mutu dan memperluas pemasaran produk.

Kemasan yang baik dan menarik merupakan salah satu strategi promosi untuk meningkatkan nilai jual produk. Meskipun suatu produk sederhana, jika dikemas dengan baik dan menarik akan memancing calon konsumen melirik produk tersebut dan membelinya. Apalagi produk pisang salee yang sudah dijadikan oleh-oleh akan semakin digemari jika kemasannya dibuat lebih baik dan menarik.

3. Meningkatnya motivasi UMKM Pisang Salee untuk mengurus PIRT

Beberapa UMKM Pisang Salee meminta kesediaan tim PKM untuk melakukan pendampingan pengurusan PIRT. Hal ini dikarenakan pengusaha pisang salee tersebut menyadari bahwa dengan adanya PIRT akan membuat produk pisang salee nya secara tidak langsung akan terstandarisasi. Selain itu, PIRT juga akan membuat konsumen merasa aman untuk mengkonsumsi produk makanan tersebut.

\section{KESIMPULAN DAN SARAN}

Produksi pisang salee dari Kota Panton Labu sudah terkenal hampir diseluruh Provinsi Aceh dan sebagian Provinsi Sumatera Utara. Pemasarannya juga tersebar di beberapa provinsi sebagai salah satu oleh-oleh khas Aceh yang digemari. Namun, pelaku usaha kuliner pisang salee belum memahami pentingnya PIRT dalam menghasilkan produk makanan agar menjamin mutu, kebersihan dan keamanan produk tersebut untuk 
dikonsumsi. Terdapat serangkaian proses yang harus dilalui oleh pelaku usaha kuliner dalam memperoleh label PIRT, antara lain manajemen berbentuk prosedur dan cara kerja untuk menghasilkan produk atau dikenal Good Manufacturing Practice (GMP).

Adapun saran yang dapat disampaikan setelah telaksananya kegiatan PKM ini adalah kegiatan ini perlu ditindaklanjuti dalam bentuk pendampingan untuk memperoleh PIRT bagi pelaku usaha kuliner/UMKM pisang salee di Kota Panton Labu. Sehingga, adanya label PIRT pada produk pisang salee akan meningkatkan mutu produk dan menambah kepercayaan konsumen akan kebersihan dan keamanannya untuk dikonsumsi. Selain itu, pelaku usaha kuliner pisang salee juga perlu mendapatkan sosialisasi tentang pentingnya kemasan/tampilan produk dalam meningkatkan daya jual.

\section{UCAPAN TERIMA KASIH}

Terima kasih kepada tim LPPM Universitas Almuslim yang telah merekomendasikan lokasi pengabdian masyarakat ini. Sosialisasi PIRT bagi UMKM Pisang Salee di Kota Panton Labu Kabupaten Aceh Utara memang sangat diperlukan untuk menunjang dan meningkatkan mutu produk pangan daerah.

\section{REFERENSI}

Badan Pengawas Obat dan Makanan (BPOM). 2018. Pedoman Pemberian Sertifikasi Produksi Pangan Industri Rumah Tangga. BPOM.

Hafni., Roswita., Ahmad, Rozali. 2017. Analisis Usaha Mikro, Kecil dan Menengah (UMKM) terhadap Penyerapan Tenaga Kerja di Indonesia. Ilmu Ekonomi dan Studi Pembangunan Vol. 15 No. 2 Hal. 77-96.

Kurniawan, Dhika Amalia., Rahma, Yudi Astuti. 2018. Pendampingan Pengurusan Izin PIRT sebagai Langkah Awal Pengembangan dan Perluasan Pasar Bagi Produk Lokal IKM Ponorogo. Khadimul Ummah, Journal of Social Dedication Vol. 1 No. 2 Hal. 55-64.

Sucipta, I. Nyoman, Ketut Suriasih., Pande Ketut Diah Kenacana. 2017. Pengemasan Pangan Kajian Pengemasan Yang Aman, Nyaman, Efektif dan Efisien. Denpasar: Udayana University Press.

Undang-undang No. 36 Tahun 2009 tentang Kesehatan. Url: https://peraturan.bpk.go.id/Home/Details/38778/uu-no-36-tahun-2009. diakses pada 24 Juli 2021. 